\title{
July/August 1983
}

Vol. 44 , No. 7

\section{Sources of Statistics}

\section{on Academic Libraries}

\author{
Sandy Whiteley \\ ACRL Program Officer
}

ACRL has long been interested in providing compilations of statistical data for academic libraries. For instance, for non-ARL university libraries, ACRL published ACRL University Library Statistics for 1978-1979 and 1981-1982 (see below). In order to determine what other statistical services ACRL should be providing for members, an ACRL Task Force on Statistics, chaired by George Bailey, Claremont Colleges, California, has been established and will report its recommendations to the ACRL Board in Los Angeles. For that Task Force I have put together a list of sources of statistics on academic libraries. What follows is a slightly expanded, though still far from complete, version of that list. I would appreciate hearing about other compilations of academic library statistics which are not included here.

The following information is arranged in four categories: national collections of data; regional collections of data; state collections of data; and collections for special types of libraries (e.g., undergraduate libraries, medical school libraries). If no price is given for published data, it is assumed to be free.

\section{National Collections of Data}

National Center for Education Statistics. This federal agency surveys academic libraries, usually biennially, as part of the Higher Education General Information Survey (HEGIS). The most recent survey was done for the year 1981-82 but the data has not yet been released. Computer tapes with the data may be available sometime this summer; the earliest possible date for publication of the final report is Fall 1983. For an historical overview of the NCES survey, see Frank Schick, "Developments in Library Statistical Activities," Bowker Annual, 27th ed., 1982, pp. 309-312.

The most recent published NCES survey for academic libraries, Library Statistics of Colleges and Universities, covers the academic year 1978-79 and was released in 1982. It includes data on 2,945 institutions. The NCES surveys are usually published in two parts: Institutional Data and Trends and Summary Data. The Institutional Data for 1978-79 is available from ERIC as ED 215679 for $83 \mathrm{c}$ in microfiche and $\$ 12.32$ in hard copy. It is also

(continued on p. 224) 


\section{Four ACRL Publications

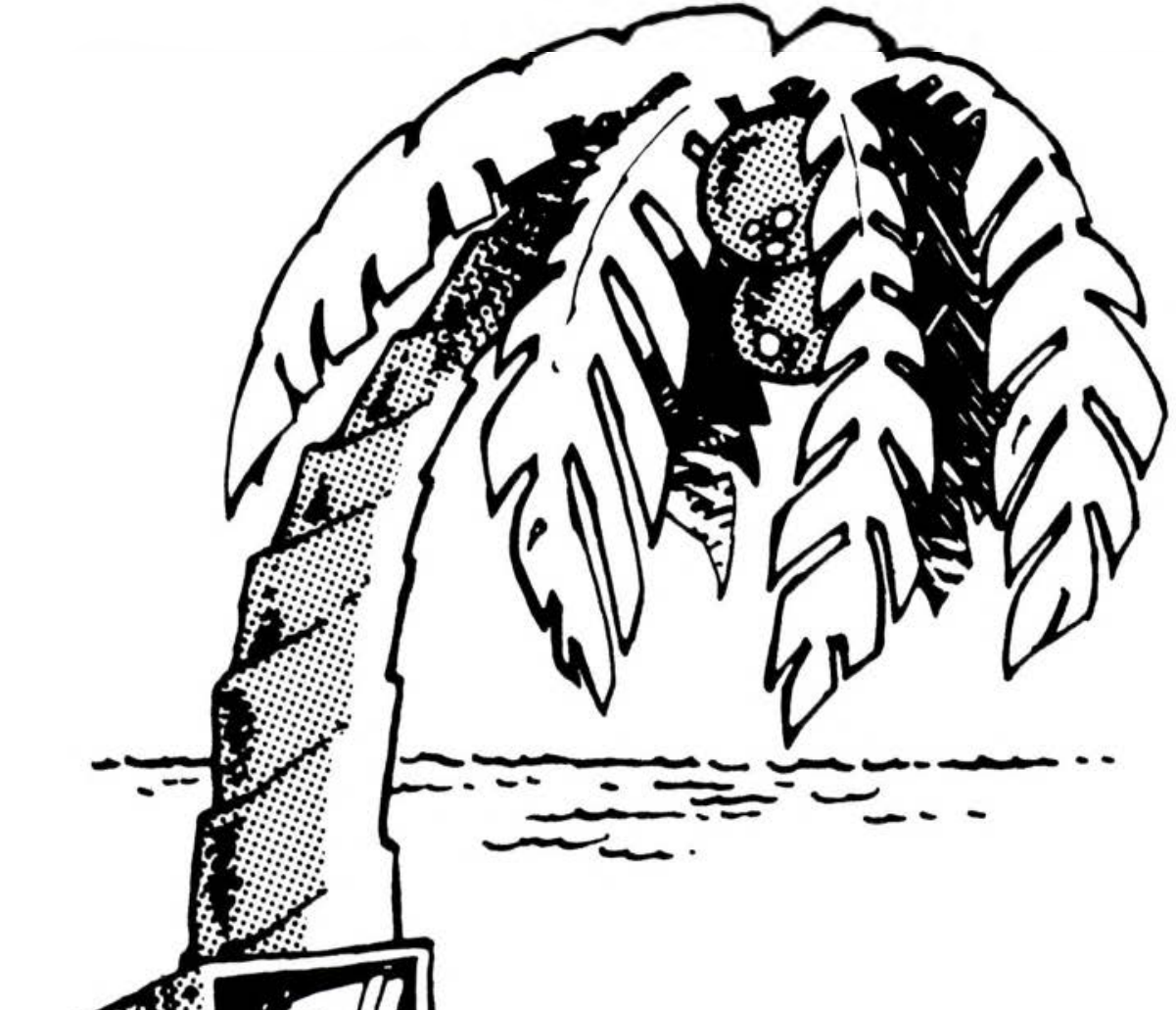 \\ that \\ every \\ academic \\ library \\ should \\ have \\ ACRL/ALA \\ 50 East Huron Street \\ Chicago, IL 60611 \\ (312) 944-6780

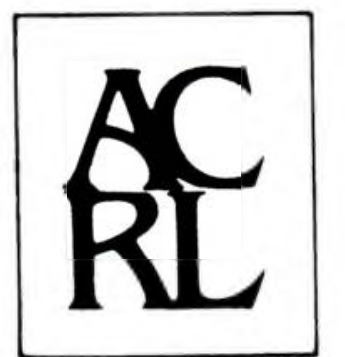

Library Statistics of Colleges and Universities: Summary Data, 1979. 1982.73 p. An analysis of data from over 3,000 academic libraries surveyed by the National Center for Education Statistics. ISBN 0-83896586-5. ACRL members: $\$ 10$. Nonmembers: $\$ 13$.

Libraries and Accreditation in Institutions of Higher Education. 1981. 176 p. ACRL members: $\$ 15$. Nonmembers: $\$ 19$.
Back to the Books: Bibliographic Instruction and the Theory of Information Sources. 1983. 76 p. Papers presented at the Bibliographic Instruction Section program at the 1982 ALA Annual Conference. ISBN 0-8389-6587-3. ACRL members: $\$ 12$. Nonmembers: $\$ 15$.

ACRL University Library Statistics 1981-1982. 1983. 60 p. Statistics from 92 U.S. and Canadian university libraries. ISBN 0-8389-6596-2. ACRL members: \$12. Nonmembers: $\$ 15$. 


\section{COLLEGE \& RESEARCH LIBRARIES NEWS}

July/August 1983

Volume 44

Number 7

\section{CONTENTS}

Sources of Statistics on Academic Libraries

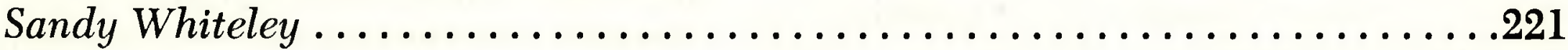

ACRL President's Report, 1982-83

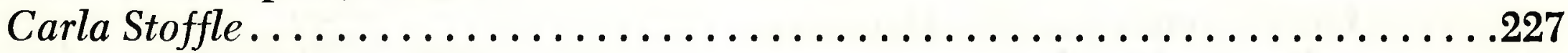

Executive Director's Report

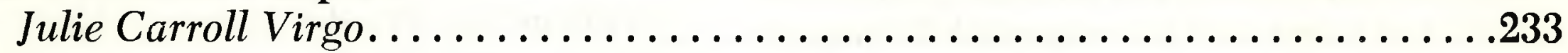

Humanities Programs for Libraries: An ACRL/NEH Workshop

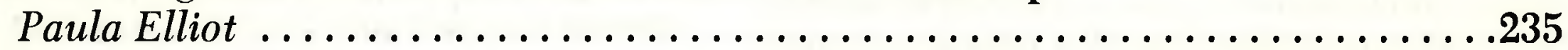

The Librarian As Library User: A Personal Comment

Mina Jane Grothey ...................................237

Washington Hotline

Carol C. Henderson ...................................239

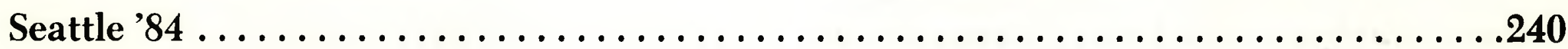

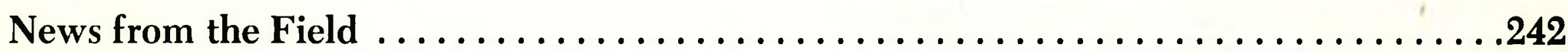

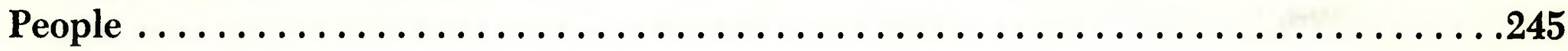

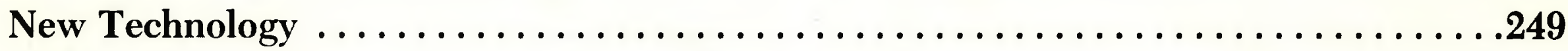

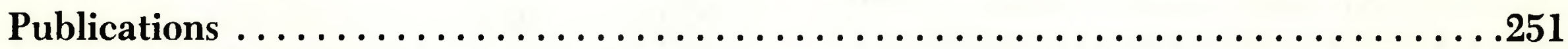

Calendar .............................................254

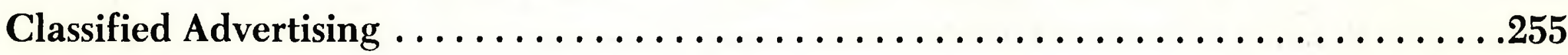

College \& Research Libraries News (ISSN 0099-0086) is published by the Association of College and Research Libraries, a division of the American Library Association, as 11 monthly (combining JulyAugust) issues, at $50 \mathrm{E}$. Huron St., Chicago, IL 60611. Annual subscription: \$10. Single copies and back issues: $\$ 3.50$ each. Second-class postage paid for at Chicago, Illinois, and at additional mailing offices.

Editor: George M. Eberhart, ACRL/ALA, 50 E. Huron St., Chicago, IL 60611; (312) 944-6780. President, ACRL: Carla J. Stoffle. Executive Director, ACRL: Julie Carroll Virgo.

Production and circulation office: $50 \mathrm{E}$. Huron St., Chicago, IL 60611. Display advertising should be sent to Choice, 100 Riverview Center, Middletown, CT 06457; (203) 347-6933. Send classified ads to ACRL. Change of address and subscription orders should be addressed to College $b$ Research Libraries News, for receipt at the Chicago address at least two months before the publication date of the effective issue. Inclusion of an article or an advertisement in $C \triangleleft R L$ News does not constitute official endorsement by ACRL or ALA.

A partial list of the services indexing or abstracting the contents of $C \triangleleft R L$ News includes: Current Contents: Social \& Behavioral Sciences; Current Index to Journals in Education; Information Science Abstracts; Library \& Information Science Abstracts; Library Literature; and Social Sciences Citation Index.

To the postmaster: Send address changes to College \& Research Libraries News, 50 E. Huron St., Chicago, IL 60611.

${ }^{\circ}$ American Library Association 1983. All material in this journal subject to copyright by the American Library Association may be photocopied for the noncommercial purpose of scientific or educational advancement. 


\section{Statistics, cont'd}

available from NTIS under accession number PB82169087 for $\$ 4$ in microfiche and $\$ 16.50$ in paper. The Trends and Summary Data volume is also usually published by the government; however, the 1978-79 summary data was published by ACRL. It is available as Library Statistics of Colleges and Universities: Summary Data, 1979, prepaid from ACRL, \$10 for ACRL members and \$13 for non-members. It has 185 pages of tables which summarize the Institutional Data, giving medians, quartiles, and other distributions.

Further information on NCES surveys is available from Richard Beazley at the National Center for Education Statistics in Washington at (301) 436-6662.

American Library Association. The ALA Survey of Librarian Salaries, by Mary Jo Lynch, Margaret Myers, and Jeniece Guy, was done for the first time in 1982 and is intended to be biennial. It contains salaries for 13 professional positions in three types of academic libraries in four regions of the United States. It is available from ALA Publishing, $50 \mathrm{E}$. Huron St., Chicago, IL 60611 for $\$ 40$.

For additional salary information, see the $A R L$ Salary Survey below.

Association of College and Research Libraries. ACRL University Library Statistics 1981-1982 is based on the annual survey done by the Association of Research Libraries (see below). Ninety-two libraries in Ph.D.-granting institutions in the United States and Canada which do not belong to ARL responded to a questionnaire based on the ARL model. Data is given on collections, expenditures, staff, and interlibrary loan. There are also rank order tables and medians for each factor. An ACRL Index was devised which ranks the libraries on an overall measure of size. ACRL University Library Statistics 1981-1982 is available prepaid from ACRL, 50 E. Huron St., Chicago, IL 60611 at $\$ 12$ for ACRL members and $\$ 15$ for non-members. Copies of the 1978-1979 survey are still available for $\$ 1$ prepaid.

Association of Research Libraries. ARL began compiling statistics for its members in 1963-64 and published them as Academic Library Statistics. In 1974-75 the title was changed to ARL Statistics. Edited by Carol A. Mandel, ARL Statistics is available annually for $\$ 10$ from the Association of Research Libraries, 1527 New Hampshire Ave., N.W., Washington, DC 20036. The 1981-82 edition contains data on 101 university libraries in the U.S. and Canada which belong to ARL. Also available from ARL is Cumulated ARL University Library Statistics, 1962-63 Through 1978-79. It was published in 1981 and sells for $\$ 15$.

From 1919 to $1962-63$ data on ARL libraries was collected by the Princeton University Library and is available now from University Microfilms International. ARL started publishing its annual Salary Survey in 1967-68 and it costs $\$ 10$ a year.
Bowker. Bowker collects statistical data to be published with each entry in the American Library Directory. Only the figures for acquisitions are published in an aggregated form (academic libraries by state) in the Bowker Annual each year. Bowker is considering leasing tapes which contain their statistical data. For more information, contact Gary Ink at Bowker.

Canadian Association of Research Libraries. Geoffrey Briggs, university librarian at Carleton University, gathers data annually for the Association. It is not published.

Council of Independent Colleges. The Council maintains a computerized database which libraries can participate in for a fee. Each library can then be compared with similar institutions. The data is not published. Librarians wanting more information should contact Willis Hubbard, college librarian at Gettysburg College.

Bowdoin List. This data is collected annually by Arthur Monke, librarian at Bowdoin College. It covers 37 small private colleges and is unpublished.

Public Service Statistics of Selected College Libraries 1981-82. Available from the compiler, Ann Bevilacqua, Franklin and Marshall College, Lancaster, Pennsylvania. It gives statistics on online searching, reference questions, etc., in libraries on the "Bowdoin List."

\section{Regional Lists}

Pacific Northwest Library Association. Library Statistics of Colleges and Universities in the Pacific Northwest 1980-81 was compiled by James D. Lockwood for the Academic Division of PNLA in cooperation with the Interinstitutional Library Council of the Oregon State System of Higher Education. It is available for $\$ 7$ from the Interinstitutional Library Council, Kerr Library, Oregon State University, Corvallis, OR 97331. Checks should be made out to PNLA. This survey, which was done once before in 1978-79, covers 138 institutions in the United States and Canada and is based on ARL Statistics.

Library Data: Associated Colleges of the Midwest and Library Data: Great Lakes College Association. These surveys are compiled annually by Dennis Ribbens, Librarian, Lawrence University, Box 599, Appleton, WI 54912. They cover 25 small, private liberal arts colleges in the Midwest.

Statistics of Southern College and University Libraries. This has been published annually since 1960 by the Louisiana State University Library, Baton Rouge. It covers 50 institutions from Maryland to Florida and as far west as Texas.

Association of Southeastern Academic and Research Libraries. Thirty-two libraries in nine states contribute to this survey which is only available to members. For more information, contact Lester Pourciau, director of libraries, Memphis State University. 


\section{State Surveys}

Almost every state publishes a statistical compilation, but in many cases it only includes public libraries. In some other cases, academic libraries are included but there is only directory-type information. For this reason, these collections are not cited here. The following states are rumored to publish statistical compilations which include academic libraries but they are not held by the ALA Headquarters Library and I have not been able to examine them: Indiana, Nevada, New Mexico, North Dakota, Oklahoma, South Carolina, Washington (community colleges only), and Wisconsin. If any readers have access to these publications, I would very much appreciate receiving information about them.

California. California Library Statistics and Directory, 1982, California State Library. Covers fiscal year 1980-81 for public, academic, special, state agency, and county law libraries. Available for $\$ 8$ from California State Department of Education, Publication Sales, PO Box 271, Sacramento, CA 95802.

University of California Library Statistics. Available from the Office of the Assistant VicePresident, Library Plans and Policies, University of California Systemwide Administration, Berkeley. Gives information on the 10 universities which make up the University of California.

Florida. Florida Library Directory with Statistics, 1973- . Tallahassee, Florida Department of State, Division of Library Services. Uses HEGIS data, published every other year.

Idaho. "Statistics for Idaho Academic Libraries," in the January issue of The Idaho Librarian. Compiled by R.J. Beck of the University of Idaho, it covers 21 institutions, public and private.

Illinois. "Higher Education General Information Survey," Illinois Libraries, 64 (September 1982):889-910. This is the data which was submitted to NCES by 14 publicly supported institutions in Illinois but which has not yet been published by NCES.

New Hampshire. New Hampshire Library Statistics, New Hampshire State Library, 1981. Very brief data on 24 institutions, public and private.

North Carolina. Statistics of North Carolina University and College Libraries (7p.), Division of State Library, North Carolina Department of Cultural Resources. Covers over 100 institutions, including community and technical colleges.

Ohio. Statistics of Ohio Libraries, State Library of Ohio, Columbus. There is a 22-page section on academic libraries covering 100 institutions, both public and private. Includes rankings of libraries by enrollment, total volumes, expenditures.

Oregon. Directory and Statistics of Oregon Libraries, Oregon State Library, Salem. Includes 5 pages covering 48 academic libraries.

South Dakota. Statistics of South Dakota Libraries, South Dakota State Library, Pierre, 1979.
Academic library statistics, pp. 33-37. Covers 16 public and private institutions.

Virginia. Statistics of Virginia Public Libraries and Institutional Libraries, Richmond, Library Development Branch, Virginia State Library. Brief data on academic libraries.

West Virginia. Statistical Report, West Virginia Library Commission, 1981. College and university statistics, pp. 17-18. Covers 27 institutions.

\section{Special Types of Libraries}

Undergraduate. "Statistical Issue," UGLI Newsletter. January of each year. A publication of the Undergraduate Librarians Discussion Group of ACRL, the Statistical Issue is compiled by Donna Senzig. The Newsletter is available from the editor, Roland Person, Undergraduate Library, Southern Illinois University, Carbondale, IL 62901. Fifty-nine pages of detailed data on the undergraduate libraries of 30 institutions.

Medical school libraries. Annual Statistics of Medical School Libraries in the United States and Canada, 5th ed., 1981-82. Available for $\$ 65$ prepaid from the Houston Academy of MedicineTexas Medical Center Library, 1133 M.D. Anderson Blvd., Houston, TX 77030.

\section{More Exchanges}

The British Library Association and its International and Comparative Librarianship Group have set up a special bureau to assist two-way exchanges, for British librarians wishing to work abroad and for librarians from other countries who wish to work in Britain, by putting them in touch with suitable exchange partners. The Bureau for International Library Staff Exchange (LIBEX) is operating for an experimental period at the College of Librarianship Wales. In 1983-1985 the Bureau will confine its activities to exchanges between Britain and four other countries only: the United States, Canada, France, and West Germany.

Interested exchangers should write to $\mathrm{A}$. Hillier, Bureau for International Library Staff Exchange, College of Librarianship Wales, Llanbadarn Fawr, Aberystwyth, Dyfed SY23 3AS, Great Britain. Inquirers will be sent a form to complete giving details of the job they wish to exchange. An abstract of each will be placed in library journals either in Britain or the most appropriate country. Librarians writing in response to an abstract will be sent a copy of the original form and will be asked to contact the originator of the form if they wish to pursue an exchange. 


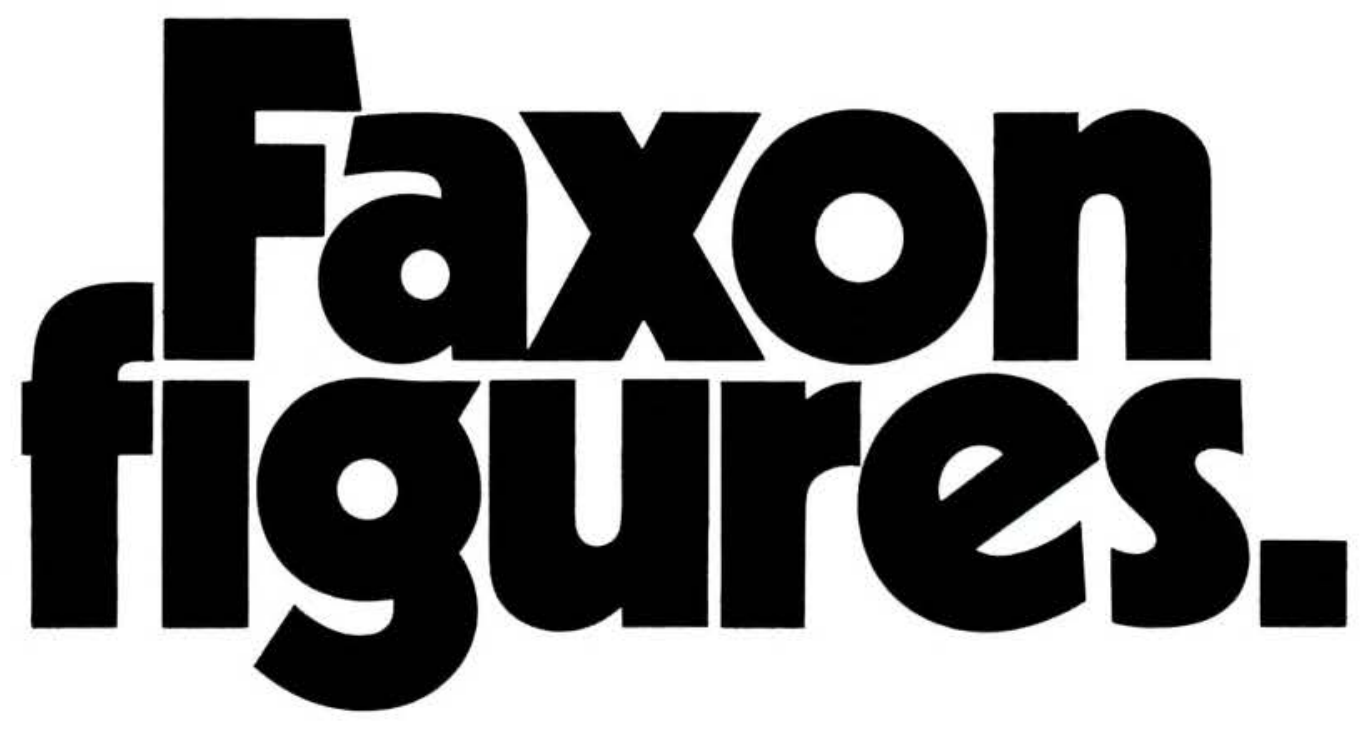

Productivity is a critical concern in today's library. That's why more and more decision makers are looking into Faxon. We can be the best source for all of your journal and continuation subscriptions. Our services enable you to devote your valuable personnel resources to other crucial library functions.

As a full service agent with access to more than 150,000 different periodicals, we can handle ordering, claiming, check-in, and routing. Our growing international network links you to other libraries, publishers, and in the near future, other online systems.

If you can profit from improved productivity, a call to Faxon figures.

$1-800-225-6055$

or 1-617-329-3350 (collect)

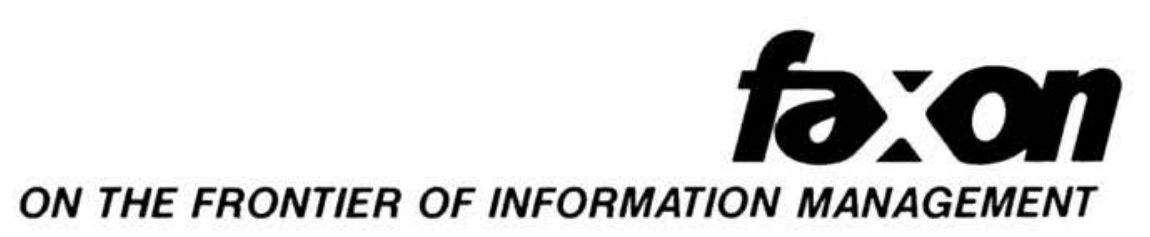

F.W. Faxon Company, Inc. 15 Southwest Park Westwood, MA 02090 